\title{
Four rare and/or threatened new species of Prostanthera Section Prostanthera (Labiatae) from New South Wales
}

\author{
Barry J. Conn
}

\begin{abstract}
Conn, B.J. (Royal Botanic Gardens, Mrs Macquaries Road, Sydney NSW 2000, Australia) 1997. Four rare and/or threatened new species of Prostanthera Section Prostanthera (Labiatae) from New South Wales. Telopea 7(3): 231-244. Prostanthera askania, P. hindii, P. junonis and P. palustris are described for the first time. Both Prostanthera askania and P. junonis are threatened by urban and industrial development in the Gosford area. Neither of these species is afforded protection because they do not occur within any conservation reserves. Prostanthera junonis is restricted to the Somersby Plateau (Gosford area). Without immediate protection from inappropriate urban and industrial development, this threatened naturally rare species is likely to become extinct in the near future. Although often locally rare, P. hindii occurs in the Wollemi National Park and does not appear to be conservationally threatened. Prostanthera palustris is a rare and possibly threatened species that is restricted to the Bundjalung National Park of north-eastern New South Wales.
\end{abstract}

\section{Introduction}

Although it is preferable that new species be described within taxonomic revisions, it is deemed important that the names of these species be published without delay, so that government and non-government agencies are aware of their conservation status.

Terminology follows Conn (1984), except inflorescence terminology as modified by Conn (1995). Conservation 'Risk Codes' are based on Briggs \& Leigh (1996).

\section{Taxonomy}

\section{Prostanthera askania B.J. Conn, sp. nov.}

Frutex erectus effusus 1-2.5 m altus. Rami subteretes, moderate tomentosi, pilis effusis vel subpatentibus (0.5-)1.5-3 mm longis, sparsim glandiferi. Folia sparsim ad moderate tomentosa; petiolus (2-)4-6(-8) mm longus; lamina ovata (12-)16-40 mm longa, (8-)14-24 mm lata, basi plus minusve attenuata ad truncata, margine penitus dentato, apice obtuso. Podium 0.8-1.8 mm longum. Prophylla $2.5-4 \mathrm{~mm}$ longa, 0.4-1 mm lata. Calyx extra moderate tomentosus intus praeter interdum basi loborum glaber, tubo 1.5-2.5 mm longo, lobis 1.8-3.5 mm longis. Corolla dilutissima malvina ad azureo-malvina, 12-14 mm longa, extra distaliter sparsim tomentosa, pilis effusis, tubo 7-8 mm longo, lobo abaxiali-mediano transverse late spathulato, c. $5 \mathrm{~mm}$ longo, apice irregulari rotundato, non bilobato, lobis lateralibus ellipticis, $4-5 \mathrm{~mm}$ longis, apice leviter irregulari rotundato, lobo adaxiali-mediano depresse ad perdepresse ovato, 3-3.5 mm longo, apice irregulari rotundato. Stamina $1.5-2 \mathrm{~mm}$ e basi corollae affixa, filamentis $2-2.2 \mathrm{~mm}$ longis, antherae $0.8-1 \mathrm{~mm}$ longae, appendice absenti. Pistillum 5.5-6.5 mm longum. Mericarpia 1.5-1.8 mm longa. 
Holotype: New South Wales: Central Coast: Pole Ford, 'Forest of Tranquillity' (Askania Park), W of Ourimbah, B.J. Conn 4140 E H.M. Conn, 25 Oct 1996 (NSW 402642); isotypes: AD, BRI, CANB, MEL.

Prostanthera sp. G sensu B.J. Conn (1992) Fl. New South Wales 3: 653.

Prostanthera sp. Strickland State Forest (J.H. Maiden s.n. 07/1915) sensu New South Wales Threatened Species Conservation Act 1995 No 101, p. 113.

Prostanthera incisa R. Br. var. pubescens auct. nonn. (e.g. Althofer 1978: 176), non F. Muell. ex Benth., Fl. Austral. 5: 96 (1870).

Erect, spreading to openly branched shrub 1-2.5 m high, rarely scrambling to $3 \mathrm{~m}$ high. Branches subterete, not or only slightly 2-ridged, moderately hairy throughout (appearing densely hairy); hairs spreading to subpatent, (0.5-)1.5-3 mm long, multicellular, white; glands scattered and usually sparse. Leaves dull 'dusty' mid-green above, paler below, strongly and somewhat unpleasantly aromatic when crushed, also with a slight cineol scent; petiole (2-)4-6(-8) mm long, hairy (similar to branches); lamina ovate, (12-)16-40 $\mathrm{mm}$ long, (8-)14-24 mm wide, hairy (similar to branches), sparsely glandular; base \pm attenuate to truncate; margin deeply toothed with teeth 5-10 mm long, directed slightly forward; apex obtuse; venation moderately distinct, especially on abaxial surface. Inflorescence a frondobracteose botryoidal conflorescence; 4-10-flowered per conflorescence. Podium 0.8-1.8 mm long, hairy (similar to branches, but usually sparser), moderately glandular. Prophylls persistent, inserted near base of calyx [propodium to anthopodium ratio 4-9], narrowly elliptic to slightly narrowly obovate, $2.5-4 \mathrm{~mm}$ long, $0.4-1 \mathrm{~mm}$ wide, moderately hairy (hairs 1-2 mm long), sparsely glandular; base attenuate; margin entire; apex attenuate; venation not visible. Calyx dull green with maroon tinge; outer surface moderately hairy, with hairs white, spreading, multicelled, 0.8-1 mm long, moderately glandular; inner surface glabrous, except occasionally with a few short hairs near base of lobes; tube 1.5-2.5 mm long; abaxial lobe transversely broad-ovate to broadly ovate, 2-3.5 $\mathrm{mm}$ long, 3-3.6 $\mathrm{mm}$ wide at base, apex rounded; adaxial lobe transversely ovate, $1.8-3 \mathrm{~mm}$ long, $3-5 \mathrm{~mm}$ wide at base, apex obtuse to rounded. Corolla 12-14 mm long, pale mauve to blue-mauve, markings absent; outer surface glabrous basally, distally sparsely hairy, hairs 0.2-0.4 mm long, spreading, very sparsely glandular; inner surface glabrous; tube 7-8 mm long; abaxial median lobes transversely broad-spathulate, c. $5 \mathrm{~mm}$ long, 5-6 mm wide, apex irregular and rounded, not bilobed; lateral lobes elliptic, 4-5 mm long, 4-5.5 mm wide, apex slightly irregular, \pm rounded; adaxial median lobe-pair depressed ovate to very depressed ovate, 3-3.5 $\mathrm{mm}$ long, 9-10 $\mathrm{mm}$ wide, apex rounded, irregular. Stamens inserted 1.5-2 $\mathrm{mm}$ above base of corolla; filaments 2-2.2 $\mathrm{mm}$ long; anthers 0.8-1 mm long, lobes cristate on basal dorsal surface and with small acumen basally, connective extended along dorsal surface of and adnate with anther, not extended beyond base of anther locule (hence, basal appendage appearing absent). Pistil 5.5-6.5 mm long. Mericarps 1.5-1.8 mm long. Fig. 1.

Flowering: (June-) September-December. Fruiting: July-December.

Other specimens examined (25 examined): New South Wales: Central Coast: Niagara Park, Conn 4129-4133, 25 Sep 1996 (NSW 401979-401983); Holgate, Tinlin s.n., 7 Nov 1988 (NSW 402658); Stellas Brush, Payne s.n., Apr 1986 (NSW 237041); Hogans Brush, Maiden s.n., Jul 1915 (NSW 128336); Kendalls Glen, Blakely s.n. E Shiress, 16 Oct 1926 (NSW 128354); Askania Park, Hardin 86023, 6 Oct 1985 (NSW 240156 \& 240169); Strickland State Forest, O’Brien s.n., 20 Sep 1987 (NSW 451469).

Distribution: this species is only known from the Gosford-Ourimbah region, New South Wales.

Habitat: this species occurs as an understorey shrub in or adjacent to rainforest dominated by Cryptocarya microneura, Acacia irrorata, Tristaniopsis collina, Callicoma 

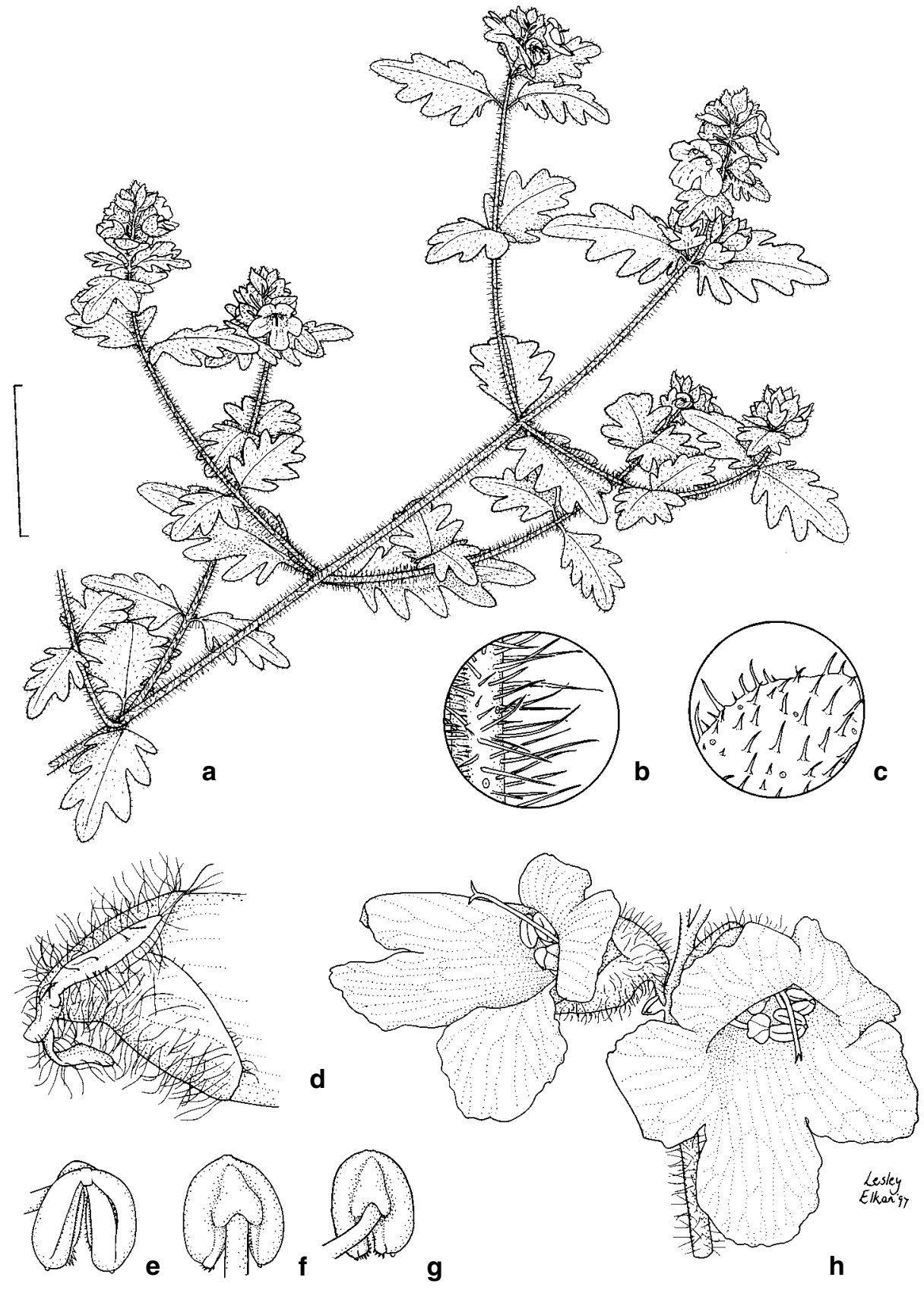

Fig. 1. Prostanthera askania. a, flowering branchlet. b, detail of branchlets showing spreading, multicellular hairs and hemispherical sessile glands. $\mathbf{c}$, detail of indumentum and hemispherical sessile glands of leaf surface. $\mathbf{d}$, detail of calyx and prophylls. e, ventral stamen, showing ventral surface. $\mathbf{f}$, ventral stamen, showing dorsal surface and connective. $\mathbf{g}$, dorsal stamen, showing dorsal surface and connective. $h$, flowers ( $\mathrm{a} \& \mathrm{~b}$ from Conn 4129; c-h from Conn 4140). Scale bar: a $=30 \mathrm{~mm}$; $\mathrm{b} \& \mathrm{c}=3 \mathrm{~mm} ; \mathrm{d}=4 \mathrm{~mm} ; \mathrm{e}-\mathrm{g}=2 \mathrm{~mm} ; \mathrm{h}=6 \mathrm{~mm}$. 
serratifolia, Eucalyptus saligna, Acmena smithii, Archontophoenix cunninghamiana, Glochidion ferdinandi. It grows in sandy soils, overlying sandstone.

Etymology: the specific epithet is an indeclinable noun in apposition that refers to the collecting locality (Askania Park, now known as 'Forest of Tranquillity') of the type material.

Notes: this species is characterised by having toothed hairy leaves, with long, subpatent, white hairs; a pale mauve to blue-mauve corolla, lacking markings; and the leaves and branches are strongly and unpleasantly aromatic, especially when crushed. The anther appendage appears to be absent because it does not extend beyond the base of the anther locule. The affinities of this species appears to be with P. incisa R.Br.; however, it is readily distinguished from the latter. Prostanthera incisa is moderately to densely hairy with short, curled hairs and although the leaves are also toothed, the teeth are much shorter than those of P. askania.

Conservation status: this species does not occur in any conservation reserves. In the Gosford area it is regarded as rare and possibly endangered (Risk Code 2RCi), especially within the Niagara Park area of the City of Gosford where it is endangered by urban development. This species is listed as 'Prostanthera sp. Strickland State Forest (J.H. Maiden s.n. 07/1915)' under the New South Wales Threatened Species Conservation Act 1995 No 101, p. 113, as 'Schedule 2, Vulnerable Species'.

Vernacular name: Tranquillity Mintbush (pers. comm. C. Manners, October 1996).

\section{Prostanthera hindii B.J. Conn, sp. nov.}

Fruticulus erectus 0.3-1 m altus. Rami in sectione transversali plus minusve transverse rhombei ad quandrangulati et quadriporcati, inter cristas dense tomentosas, pilis antrorsis plus minusve adpressis, usque ad $0.2 \mathrm{~mm}$ longis, dense glandiferi. Folia praeter interdum in petioli et basi lamiae glabra; petiolus usque ad 1-2 mm longus; lamina ovata ad anguste ovata, (10-)15-25(-30) mm longa, 4-8(-12) $\mathrm{mm}$ lata, basi breviter attenuata, margine integro, apice obtuso. Podium $2.7-3 \mathrm{~mm}$ longum. Prophylla 3-4 mm longa, c. $1 \mathrm{~mm}$ lata. Calyx extra praeter margine loborum et tubus glaber, tubo 2.5-3 mm longo, glabro, lobis 4-5 mm longis. Corolla malvina, fauce atromalvina ad atropurpurea colorata, 10-14 mm longa, extra distaliter moderate ad dense tomentosa, pilis antrorsis ad leviter effusis, tubo 5-7 mm longo, lobo abaxiali-mediano late spathulato, 5-6.5 mm longo, apice irregulari rotundato, plerumque leviter bilobato, lobis lateralibus plus minusve ellipticis, 5-5.5 mm longis, apice leviter irregulari rotundato ad leviter retuso, lobo adaxiali-mediano latissime ovato, c. $5 \mathrm{~mm}$ longo, apice rotundato irregulari, non bilobato vel leviter bilobato. Stamina $1.2-1.5 \mathrm{~mm}$ e basi corollae affixa, filamentis $1.5-2 \mathrm{~mm}$ longis, antherae $1.2-1.6 \mathrm{~mm}$ longae, acumine inflato, appendice absenti. Pistillum 11-12.5 mm longum. Mericarpia 1.3-1.8 mm longa.

Holotype: New South Wales: Central Tablelands: Wollemi National Park, Glow-worm Tunnel road, Newnes Plateau, Conn 2649, Hind, Porter $\mathcal{E}$ Scott, 8 Oct 1987 (NSW 196227); isotypes: MEL, NY.

Prostanthera sp. D sensu B.J. Conn (1992) Fl. New South Wales 3: 652.

Prostanthera sp. 9 (Newnes Plateau; B.J. Conn 2647) sensu Briggs \& Leigh (1996).

Erect subshrub, 0.3-1 m high. Branches \pm transversely rhombic to quadrangular in section, laterally 2-ridged, usually densely hairy, with hairs restricted to area between the ridges; hairs antrorse, \pm appressed, to $0.2 \mathrm{~mm}$ long, white; densely glandular, especially between ridges, with glands scattered and less dense elsewhere. Leaves dark green above, paler below, frequently with a maroon midrib and margin, non-aromatic or only faintly so, glabrous, except sometimes with a few hairs on petiole, near base of lamina, rarely with 1-4 hairs on basal third of margin (hairs as for branches); petiole 
1-2 mm long; lamina ovate to narrowly ovate, (10-)15-25(-30) mm long, 4-8(-12) mm wide, lower surface sparsely glandular; base shortly attenuate; margin entire, slightly recurved; apex obtuse; venation indistinct, midrib raised. Inflorescence a frondose botryoidal (racemiform) conflorescence, uniflorescence monadic; 4-10-flowered per conflorescence. Podium 2.7-3 mm long, sparsely hairy (hairs as for branches), sparsely to moderately glandular. Prophylls persistent, inserted near calyx [propodium to anthopodium ratio $2.8-5.5(-8)$ ], narrowly obovate to narrowly elliptic, 3-4 mm long, c. $1 \mathrm{~mm}$ wide, glabrous, except for hairs on margin (hairs as for branches), sparsely glandular; base attenuate; margin entire, \pm incurved; apex obtuse; venation not visible. Calyx maroon, with or without a green tinge; outer surface glabrous, except for margin of lobes (especially abaxial lobes) and an occasional hair on surface of tube; hairs white, \pm antrorse, appressed or \pm patent on apex of lobes, to $0.2 \mathrm{~mm}$ long, moderately glandular; tube 2.5-3 mm long, glabrous; abaxial lobe very broadly ovate, c. $4 \mathrm{~mm}$ long, c. $4 \mathrm{~mm}$ wide, apex rounded to \pm truncate, inner surface densely hairy distally (including apex); adaxial lobe very broadly ovate to ovate, c. $5 \mathrm{~mm} \mathrm{long}, 4.5-5.5 \mathrm{~mm}$ wide, apex rounded, inner surface densely hairy in a band just below the apex. Corolla 10-14 mm long, mauve, with deep mauve to dark purple coloration in throat; outer surface glabrous basally, distally moderately to densely hairy, hairs to $0.2 \mathrm{~mm}$ long, antrorse to slightly spreading, sparsely glandular; inner surface glabrous, except adaxial surface of mouth and base of adaxial median lobe-pair sparsely hairy, hairs as for outer surface; tube 5-7 mm long; abaxial median lobes broadly spathulate, $5.5-6.5 \mathrm{~mm}$ long, 4.2-6.3 mm wide, apex irregular and rounded, usually slightly bilobed; lateral lobes \pm elliptic, 5-5.5 $\mathrm{mm}$ long, $4-5 \mathrm{~mm}$ wide, apex slightly irregular, rounded to slightly retuse; adaxial median lobe-pair very broadly ovate, c. $5 \mathrm{~mm}$ long, c. $7 \mathrm{~mm}$ wide, apex irregular and rounded, not or only slightly bilobed. Stamens inserted 1.2-1.5 mm above base of corolla; filaments 1.5-2 mm long; anthers 1.2-1.6 mm long, lobes cristate on basal dorsal surface (narrowly triangular trichomes $0.1-0.2 \mathrm{~mm}$ long) or trichomes absent, acumen strongly extended into a prominent basal swelling $(0.5-0.8 \mathrm{~mm}$ long) which lacks trichomes apically, connective not extended to form a basal appendage. Pistil 11-12.5 mm long. Mericarps 1.3-1.8 mm long. Fig. 2.

Flowering and fruiting: (June-) September-October.

Other specimens examined (15 examined): New South Wales: Central Tablelands: Upper Cudgegong River, $1 \mathrm{~km} \mathrm{~S}$ of Kandos Weir, Crisp 2255 \& Telford, 27 Oct 1976 (NSW 405528); Old Coach Road, Newnes Plateau, Hind 5627, 8 Jun 1988 (NSW 212586); c. 6 miles E of Olinda on road to Mt Coricudgy, Whaite 3309 \& Whaite, 02 Sep 1969 (NSW 405529 \& 405530); Currant Mountain Gap (Khyber Pass), c. 5 km E of Olinda, Rylstone District, Chapman 1441, 29 Sep 1979 (NSW 405527, CANB, MEL); Carrick 3221, 25 Oct 1972 (AD, NSW 405525). Central Coast: Green Gully, Glen Davis, Constable 7208, 27 Oct 1966 (NSW 405532 \& 96490).

Distribution: this species is confined to the Central Tablelands of New South Wales, except for one collection that is from just within the Central Coast region (Constable 7208).

Habitat: this species is confined to Eucalyptus woodlands with an understorey shrubbery of Lepidosperma sp., Leptospermum sp., Leucopogon sp., Platysace sp. and Calytrix tetragona, occurring in quartz-rich sandy soil of rocky sandstone or conglomerate platforms and outcrops, amongst steep rocky turret faces and deep rubble-filled fissures.

Etymology: the specific epithet acknowledges the considerable contribution that Mr Peter Hind (NSW) has made to our understanding of the flora of Australia, and in particular, to the flora of the Newnes Plateau of the Wollemi National Park. He is also joint collector of the type material.

Notes: although most species of Prostanthera have small acumens on the base of the anthers, this species is characterised by having the acumens strongly extended into 


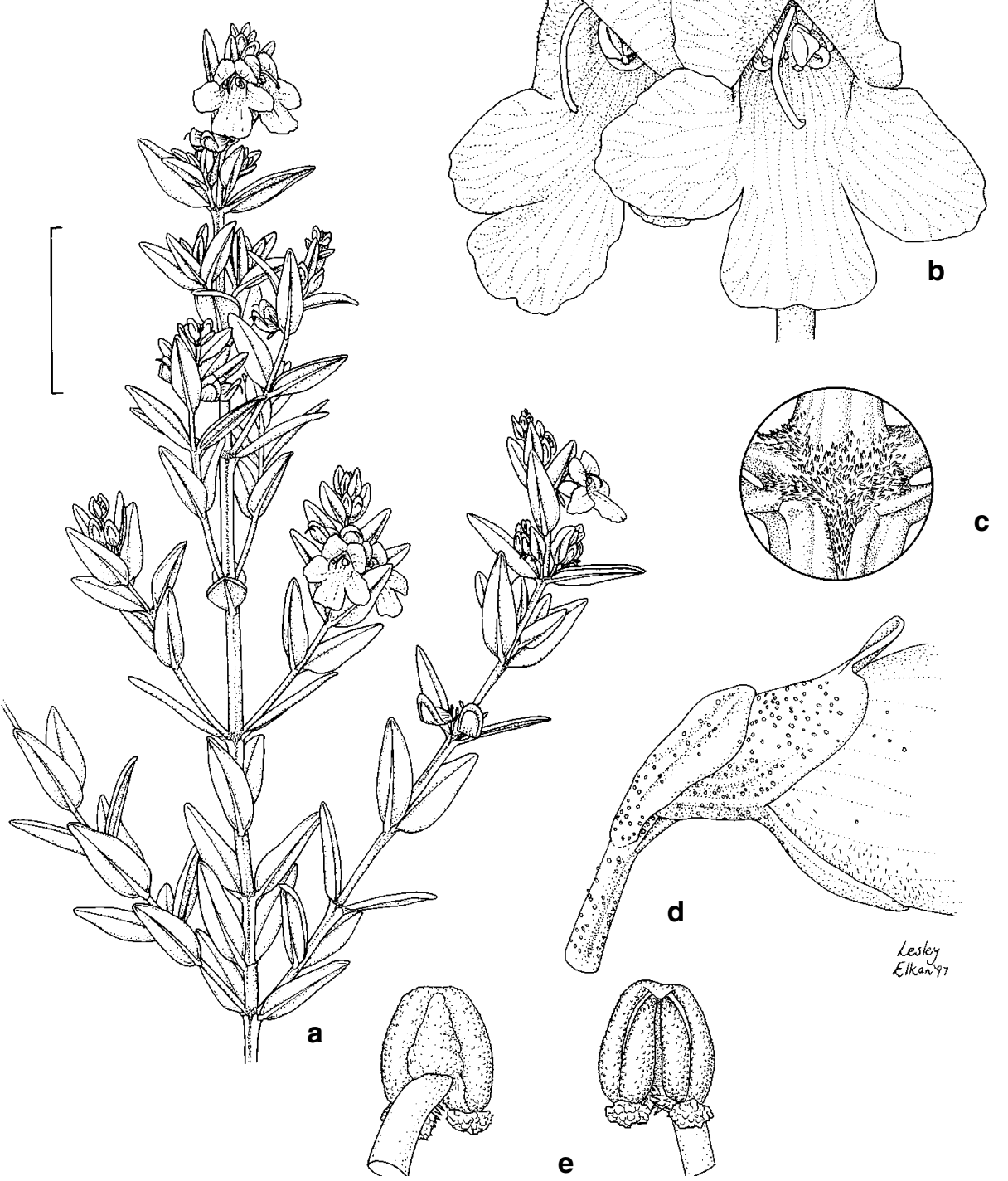

Fig. 2. Prostanthera hindii. a, flowering branchlet. b, flowers. c, detail of indumentum at nodes and between longitudinal ridges of branchlets. $\mathbf{d}$, detail of calyx and prophylls. e, stamens, showing dorsal and ventral surfaces and enlarged acumen (a \& c from Hind 5627; b, d \& e from Conn 2649). Scale bar: $\mathrm{a}=30 \mathrm{~mm} ; \mathrm{b}=6 \mathrm{~mm} ; \mathrm{c}=3 \mathrm{~mm} ; \mathrm{d}=4 \mathrm{~mm}$; $=2 \mathrm{~mm}$. 
prominent basal swellings $0.5-0.8 \mathrm{~mm}$ long. A basal appendage of the connective is absent. However, care should be taken when observing the anthers, since the strongly extended acumen may be mistaken for a connective appendage. Although the branches appear to be glabrous, short appressed hairs are confined to a longitudinal region between the lateral ridges.

Conservation status: the conservation status of Prostanthera hindii is not fully known. However, it appears to be a rare, with a very localised disjunct distribution (Risk Code $=2 \mathrm{RCi}$ ). It is afforded some protection since it occurs in the Wollemi National Park.

\section{Prostanthera junonis B.J. Conn, sp. nov.}

Fruticulus humilis effusus debilis $0.1-0.3$ m altus. Rami subteretes, sparsim tomentosi, pilis antrorsis plus minusve adpressis, $0.1-0.5 \mathrm{~mm}$ longis, sparsim glandiferi. Folia sparsim ad moderate tomentosa; petiolus usque ad 1-2(-3) $\mathrm{mm}$ longus; lamina elliptica ad anguste obovata, saepe aspectu teres, 8-16 mm longa, 1-6 mm lata, basi attenuata, margine integro, apice plus minusve obtuso. Podium 1.5-2.5 mm longum. Prophylla $0.7-0.9 \mathrm{~mm}$ longa, $0.1-0.2 \mathrm{~mm}$ lata. Calyx extra sparsim ad dense tomentosus intus praeter os ad lobi glaber, tubo 2-2.8 mm longo, lobis 1.5-1.8 mm longis. Corolla dilutissime malvina ad fere alba, 8-12 mm longa, extra distaliter sparsim tomentosa, pilis plus minusve antrorsis, plus minusve adpressis ad leviter effusis, tubo 5-6 mm longo, lobo abaxiali-mediano spathulato ad late spathulato, $4.5-6 \mathrm{~mm}$ longo, apice leviter irregulari rotundato, plerumque bilobato, lobis lateralibus angulato-ellipticis ad leviter rhombeis, 4-5 mm longis, retusis, lobo adaxiali-mediano depresse ad perdepresse ovato, 2-2.5 mm longo, apice rotundato irregulari bilobato. Stamina $2-2.5 \mathrm{~mm}$ e basi corollae affixa, filamentis $1.6-2.2 \mathrm{~mm}$ longis, antherae $0.7-0.9 \mathrm{~mm}$ longae, appendice 0.5-0.7 mm longa. Pistillum 5.5-6 mm longum. Mericarpia 1.5-2 $\mathrm{mm}$ longa.

Holotype: New South Wales: Central Coast: Somersby, WNW of Gosford, Conn 4024 E Brown, 10 Dec 1993 (NSW 280868); isotypes: BRI, K, MEL.

Prostanthera sp. Somersby (B.J. Conn 4024) sensu New South Wales Threatened Species Conservation Act 1995 No 101, p. 91.

Prostanthera marifolia p.p. ('Mangrove Mtn population') sensu B.J. Conn (1992) Fl. New South Wales 3: 650 \& 651, non R. Br. (1810) Prodr. 509.

Low spreading, decumbent, weak subshrub, 0.1-0.3 $\mathrm{m}$ high, frequently and possibly usually stoloniferous (also refer Tierney 1996, Fig. 3.1). Branches subterete, sparsely to moderately hairy; hairs antrorse, \pm appressed, 0.1-0.5 $\mathrm{mm}$ long, white; glands scattered and usually very sparse. Leaves dull green above, paler below, non-aromatic; petiole to 1-2(-3) $\mathrm{mm}$ long, grading into base of lamina (when lamina basally attenuate); lamina either elliptic to narrowly elliptic (especially near base of plant and on primary axes), 8-14 $\mathrm{mm}$ long, 3-6 $\mathrm{mm}$ wide, or narrowly obovate and often appearing almost linear when adaxial surface deeply grooved such that both sides almost touching each other, 8-16 mm long, 1-4 mm wide, sparsely to moderately hairy, particularly on midrib and margin of abaxial surface, hairs $0.3-0.4 \mathrm{~mm}$ long; base attenuate, sometimes obtuse; margin entire; apex \pm obtuse; venation indistinct, midrib slightly raised on abaxial surface. Inflorescence a frondose racemiform conflorescence, uniflorescence monadic; 4-14-flowered [per conflorescence], appearing as single flowers in axils. Podium 1.5-2.5 mm long, glandular, sparsely to moderately hairy (similar to branchlets and leaves). Prophylls persistent, inserted just below the calyx [propodium to anthopodium ratio 5-8], narrowly oblong to linear, $0.7-0.9 \mathrm{~mm}$ long, $0.1-0.2 \mathrm{~mm}$ wide, with a few scattered hairs (similar to branchlets and leaves), not noticeably glandular; margin entire; apex attenuate. Calyx green, usually with maroon-red tinge, especially on adaxial surface; outer surface sparsely to densely hairy, especially on abaxial surface of tube and on abaxial lobe, including 
margin of both lobes, adaxial surface (including lobe) usually sparsely hairy but sometimes glabrous, with hairs white, appressed, antrorse, (0.1-)0.3-0.4 mm long, sparsely glandular; tube 2-2.8 mm long, with inner surface glabrous except for a few scattered hairs and glands at mouth (hairs \pm patent, to $0.1 \mathrm{~mm}$ long); lobes with inner surface moderately hairy at least on basal half with \pm patent hairs to $0.1 \mathrm{~mm}$ long; abaxial lobe depressed ovate, 1.7-1.8 $\mathrm{mm}$ long, $2.7-3 \mathrm{~mm}$ wide at base, apex rounded; adaxial lobe depressed ovate to slightly depressed angular-ovate, $1.5-1.8 \mathrm{~mm}$ long, 3-3.5 mm wide at base, margin slightly repand, apex obtuse to rounded. Corolla 8-12 mm long, very pale mauve to almost white (fading with age), except tube abaxially white, with dull yellow-orange to pale brown dots on inner abaxial-median surface and laterally with pale purple stripes; outer surface glabrous basally, distally sparsely to moderately hairy, extending to at least half-way up lateral lobes, hairs \pm appressed to slightly spreading, \pm antrorse, $0.4-0.7 \mathrm{~mm}$ long, sparsely glandular; inner surface glabrous, except mouth and base of lobes sparsely hairy; tube $5-6 \mathrm{~mm}$ long; abaxial median lobes spathulate to broadly spathulate, 4.5-6 mm long, 4-5.5 mm wide, apex slightly irregular and rounded, usually bilobed; lateral lobes angular-elliptic to slightly rhombic, 4-5 mm long, (2-)3-3.5 mm wide, apex slightly irregular, \pm retuse; adaxial median lobe-pair depressed ovate to very depressed ovate, 2-2.5 mm long, 6-7 mm wide, apex rounded, irregular, bilobed. Stamens inserted 2-2.5 $\mathrm{mm}$ above base of corolla; filaments $1.6-2.2 \mathrm{~mm}$ long; anthers $0.7-0.9 \mathrm{~mm}$ long, lobes with a few narrowly triangular trichomes on basal dorsal surface and with small acumen basally, connective extended to form a basal appendage $0.5-0.7 \mathrm{~mm}$ long. Pistil 5.5-6 mm long. Mericarps 1.5-2 mm long. Fig. 3.

Flowering: (July-) October-February. Fruiting: October-December (-February)

Selected specimens examined (18 collections): New South Wales: Central Coast: Wisemans Ferry road, from Gosford, Blakely \& Shiress s.n., Sep. 1926, (NSW 126729, 451449-451451); Between Piles Creek and Mooney Mooney, Blakely E Shiress s.n., 4 Oct. 1926 (NSW 126725, 451452-451455); Mangrove Mountain, Blakely, Murphy, Shiress \& Bott s.n., 18 July 1926 (NSW 126723, 451456-451460); Somersby: Conn 4023, 4025-4026 \& Brown, 10 Dec. 1993 (NSW 280855, 280871, 280902); Conn 4028 E Brown, 10 Dec. 1993 (NSW 280907); Conn 4102-4104 \& Godden, 29 Nov. 1995 (NSW 392970, 393061, 393062); Conn 4127 \& Radford, 24 Sep. 1996 (NSW 401977); Conn 4139 \& Conn, 25 Oct. 1996 (NSW 402485).

Distribution: this species is only known from the Somersby Plateau of the City of Gosford, Central Coast Region, New South Wales.

Habitat: this species frequently occurs along drainage lines or in seepage areas, usually in shallow, coarse gravelly white-grey sandy soils overlying Hawkesbury Sandstone. This substrate supports an open woodland community dominated by trees of Corymbia gummifera (formerly Eucalyptus gummifera), Angophora costata, A. hispidula, Eucalyptus haemastoma, E. piperita, E. punctata and E. sieberi. The understorey is dominated by a more or less dense cover of rushes and sedges (including Empodisma minus and Lepyrodia scariosa), and shrubs and subshrubs (including Acacia oxycedrus, A. suaveolens, Banksia ericifolia, B. serrata, Bauera rubioides var. microphylla, Darwinia fascicularis, Dillwynia floribunda, Epacris obtusifolia, Grevillea buxifolia, G. sericea, G. speciosa, Hakea sericea, H. teretifolia, Hemigenia purpurea, Kunzea capitata, Leptospermum polygalifolium, Persoonia isophylla, P. levis, Petrophile pulchella, Pimelea linifolia, Sprengelia incarnata, Thelionema umbellata).

Etymology: the specific epithet honours Mrs June Gay who generously assisted my research into the genus Prostanthera by voluntarily assisting with the electronic capture of the herbarium-label data of the research material of this genus. She also provided considerable curatorial support for the material of this genus held in the National Herbarium of New South Wales. After a long illness, June died on 30 September, 1997. Her friendship will be deeply missed. 


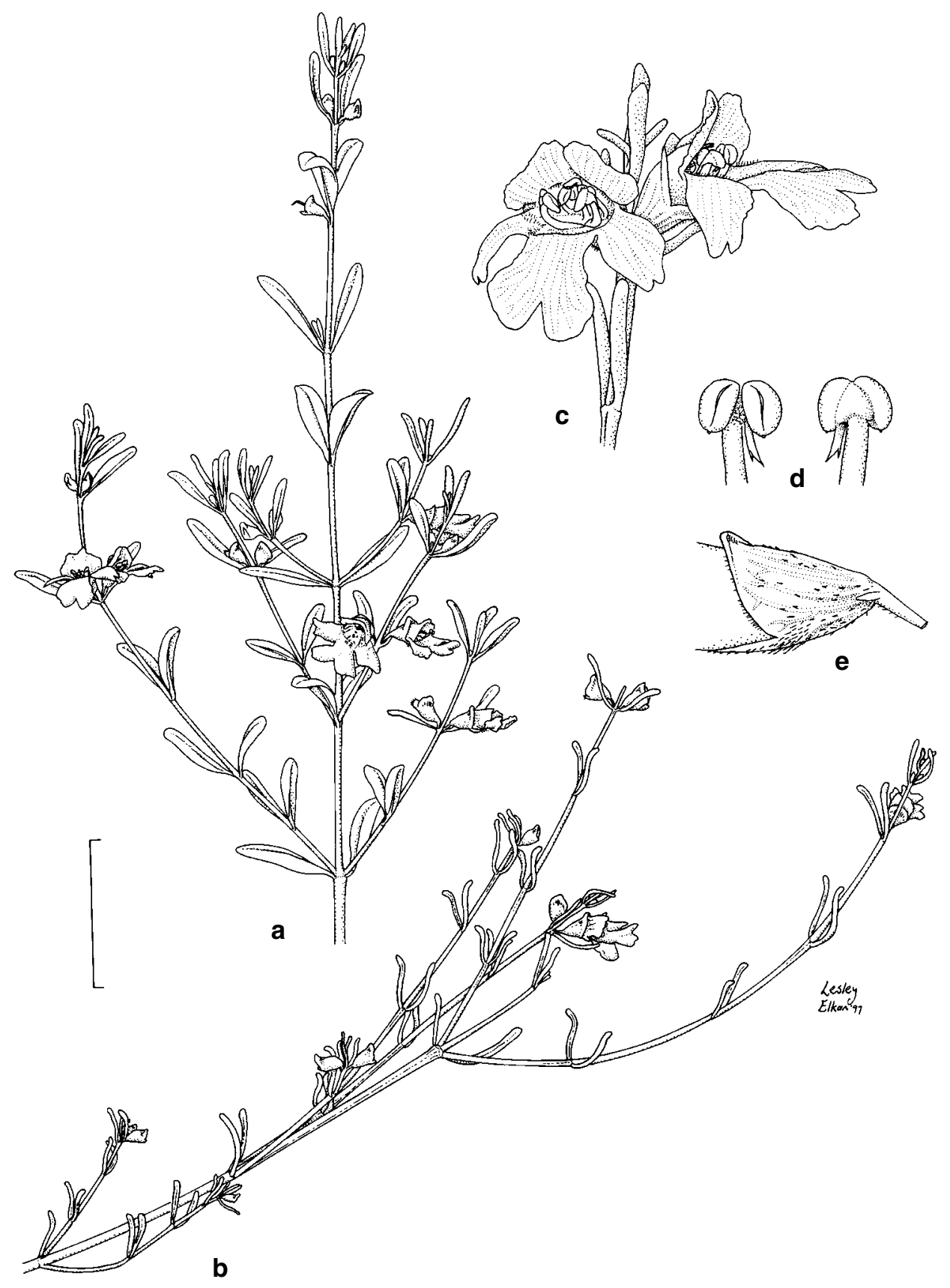

Fig. 3. Prostanthera junonis. $\mathbf{a}$, erect flowering branchlet with broad leaves. $\mathbf{b}$, flowering branchlet of a subprostrate shrub with narrow leaves. c, flowers. d, stamens, showing ventral and dorsal surfaces. e, detail of calyx and prophylls (a from Conn 4025; b from Conn 4024; c-e from Conn 4139). Scale bar: $\mathrm{a} \& \mathrm{~b}=20 \mathrm{~mm} ; \mathrm{c}=6 \mathrm{~mm} ; \mathrm{d}=2 \mathrm{~mm}$; $=4 \mathrm{~mm}$. 
Notes: this species is characterised by having small pale mauve flowers, each anther with an appendage, and dimorphic non-aromatic leaves (juvenile leaves elliptic to narrowly elliptic; mature leaves narrowly obovate and often appearing almost linear). The affinities of this species are not known.

Since this new species was not included in the Flora of New South Wales account of the genus (Conn 1992), the following modifications to the identification key are necessary. Note: the older plants usually have mostly, if not entirely, narrowly obovate to almost linear leaves (identified via the modified key lead 43, below), whereas the broader, elliptic to narrowly elliptic leaves that occur on the younger plants or persist near the base of older ones, are identified using the modified key lead 44 (below).

\section{Couplet 43 (p. 648)}

43 Leaves narrowly obovate (often appearing almost linear) or linear, conduplicate or incurved, usually appearing \pm terete

43a Erect shrub 1-4 $\mathrm{m}$ high; adaxial calyx lobe 3-5 mm long; corolla 14-18 $\mathrm{mm}$ long; anther appendage c. $1.5 \mathrm{~mm}$ long; leaf lamina $10-50 \mathrm{~mm}$ long, 0.5-2 mm wide

34 P. nivea

43a* Low spreading, decumbent or subprostrate, or weakly erect subshrub, $0.1-0.3 \mathrm{~m}$ high; adaxial calyx lobe 1.5-1.8 mm long; corolla 8-12 mm long; anther appendage $0.5-0.7 \mathrm{~mm}$ long; leaf lamina 8-16 $\mathrm{mm}$ long, 1-4 mm wide (note: elliptic to narrowly elliptic leaves are also present on young plants or near the base of older plants) P. junonis

$43^{*}$ Leaves \pm flat or slightly channelled above; margin slightly incurved or slightly recurved

44 Branches (often appearing glabrous) with opposite decussate longitudinal bands of hairs

45 Leaves obovate to \pm spathulate; calyx with inner surface glabrous and outer surface densely hairy 31 P. palustris

$45^{*} \quad$ Leaves linear to ovate or elliptic, sometimes also with a few leaves narrowly obovate; calyx variously hairy or glabrous throughout

46 Strongly aromatic shrub; branches with shortly curled or long spreading hairs; leaves with margin obscurely toothed; calyx glabrous

2 P. cryptandroides

46* Non-aromatic or faintly aromatic subshrub to shrub; branches with short, \pm straight, antrorse hairs; leaves with margin entire; calyx hairy on inner surface

46a Erect shrub to $2 \mathrm{~m}$ high; calyx with outer surface glabrous or almost so

16 P. hindii

46a* Low spreading, decumbent, weak subshrub, erect when young, 0.1-0.3 $\mathrm{m}$ high; calyx with outer surface sparsely to densely hairy, especially on abaxial surface of tube and abaxial lobe

P. junonis

Conservation status: although Prostanthera junonis is a colonising species, the habitat of all populations has been severely disturbed by anthropogenic pressures. Some sites have been extensively cleared as part of urban development activities, with the 
vegetation being largely removed. However, more importantly, on some sites there has been extensive removal and/or partial relocation of soil.

The total number of individuals of this species occurring on any one site is difficult to calculate. However, there are probably fewer than 10 individuals at some sites, with up to 80-150 plants at the largest site. The long-term viability of the plants on the latter site is extremely doubtful because these 'individuals' face the greatest threats from inappropriate development, many are only young plants and, since the species is clonal, many 'individuals' are probably the same plant. The threats to the longevity of this species are both many and considerable. The current urban development activities have proven to be totally incompatible with the maintenance of a viable population of this species. Not only have the plants been directly affected by soil movement activities and the removal of other components of the vegetation, but also indirectly by changes in the substrate and micro-topographic characteristics which have resulted in soil changes, drainage pattern changes and increased erosion and sedimentation (particularly since November 1995, Tierney 1996). Other human activities, particularly recreational ones, such as horse-riding and trail-bike riding, present serious threats to the sustainability of the population (Conn 1996).

This species is regarded as extremely rare, highly endangered and is not included in a conservation reserve (Risk Code = 2E; sensu Briggs \& Leigh 1996). Without immediate protection from inappropriate urban and industrial development, this species is likely to become extinct in the near future. Active management of the known populations appear to be necessary to ensure the survival of the species. This species is listed as 'Prostanthera sp. Somersby (B.J. Conn 4024)' under the New South Wales Threatened Species Conservation Act 1995 No 101, p. 91, as 'Schedule 1, Endangered Species'.

Vernacular name: Somersby Mintbush (as used in unpublished reports).

\section{Prostanthera palustris B.J. Conn, sp. nov.}

Fruticulus humilis effusus debilis $0.2-0.3 \mathrm{~m}$ altus. Rami subteretes, quadriporcati, inter cristas tomentosas, pilis antrorsis plus minusve adpressis, $0.4-0.7 \mathrm{~mm}$ longis, sparsissime glandiferi. Folia sparsim tomentosa; petiolus 1-2 $\mathrm{mm}$ longus; lamina spathulata, (3-)4-6(-8) mm longa, (2.5-)3.5-5 mm lata, basi attenuata, margine integro, apice rotundato. Podium $0.5-1.4 \mathrm{~mm}$ longum. Prophylla $1.2-1.5 \mathrm{~mm}$ longa, $0.2-0.3 \mathrm{~mm}$ lata. Calyx extra distalibus dense tomentosus intus glaber, tubo $2.5-3 \mathrm{~mm}$ longo, lobis 1.5-3 mm longis. Corolla dilutissima malvina, fauce et tubo abaxiali-mediano albo punctis cernis, $8-10 \mathrm{~mm}$ longa, extra distaliter sparsim ad moderate tomentosa, pilis effusis, tubo c. $4 \mathrm{~mm}$ longo, lobo abaxiali-mediano transverse late spathulato, $4-4.5 \mathrm{~mm}$ longo, apice irregulari rotundato, plerumque bilobato, lobis lateralibus ellipticis, c. 4 $\mathrm{mm}$ longis, apice leviter irregulari rotundato ad leviter retusis, lobo adaxiali-mediano depresse ad perdepresse ovato, $2.3-2.5 \mathrm{~mm}$ longo, apice irregulari rotundato. Stamina $1.2-1.5 \mathrm{~mm}$ e basi corollae affixa, filamentis $2.2-3.7 \mathrm{~mm}$ longis, antherae $0.8-1 \mathrm{~mm}$ longae, appendice $0.5-0.6 \mathrm{~mm}$ longa. Pistillum $5.5-6 \mathrm{~mm}$ longum. Mericarpia $1-1.8 \mathrm{~mm}$ longa.

Holotype: New South Wales: North Coast: Bundjalung National Park: Jerusalem Creek Track, c. $0.6 \mathrm{~km} \mathrm{~N}$ of The Gap Road junction with road to Booroora Rest Area, Conn 3471, 20 Feb 1990 (NSW 224785); isotypes: PERTH, MEL, MO, AD, BRI.

Prostanthera sp. F sensu B.J. Conn (1992) Fl. New South Wales 3: 657.

Prostanthera sp. 7 sensu Quinn, Williams, Gross and Bruhl (without date), Report on Rare and Threatened Plants of North-eastern New South Wales, p.211.

Prostanthera sp. Bundjalung National Park (B.J. Conn 3471) sensu New South Wales Threatened Species Conservation Act 1995 No 101, p. 113. 
Low spreading, weak subshrub, 0.2-0.3 m high. Branches subterete, laterally 2-ridged, hairs restricted to area between the ridges; hairs antrorse, \pm appressed, $0.4-0.7 \mathrm{~mm}$ long, white; glands scattered and usually very sparse. Leaves dull green above, paler below, non-aromatic; petiole 1-2 $\mathrm{mm}$ long, grading into base of lamina; lamina spathulate, (3-)4-6(-8) mm long, (2.5-)3.5-5 mm wide, sparsely hairy, particularly on midrib and veins, hairs $0.3-0.4 \mathrm{~mm}$ long; base attenuate; margin entire, slightly recurved; apex rounded; venation indistinct, midrib slightly raised basally. Inflorescence a frondose racemiform conflorescence, uniflorescence monadic; 4-10-flowered [per conflorescence]. Podium 0.5-1.4 mm long, glandular, glabrous or with an occasional hair. Prophylls not persistent, usually only base persisting, inserted just below the calyx [propodium to anthopodium ratio 3.5-6.7], narrowly elliptic, $1.2-1.5 \mathrm{~mm}$ long, $0.2-0.3 \mathrm{~mm}$ wide, moderately hairy (hairs $0.1-0.2 \mathrm{~mm}$ long), sparsely glandular; base attenuate; margin entire, slightly recurved; apex attenuate; venation not visible. Caly $x$ light green; outer surface glabrous basally, densely hairy near mouth and on margin of lobes, with hairs white, spreading, multicelled, 0.8-1 mm long, moderately glandular; inner surface glabrous; tube $2.5-3 \mathrm{~mm}$ long; abaxial lobe transversely broad-ovate to broadly ovate, $1.5-3 \mathrm{~mm}$ long, 3-3.6 $\mathrm{mm}$ wide at base, apex rounded; adaxial lobe transversely ovate, $1.5-2 \mathrm{~mm}$ long, 2.6-3.5 mm wide at base, apex obtuse to rounded. Corolla $8-10 \mathrm{~mm}$ long, pale mauve, white with deep yellow dots in throat and inner abaxial-median surface of tube; outer surface glabrous basally, distally sparsely to moderately hairy, hairs $0.2-0.4 \mathrm{~mm}$ long, spreading, sparsely glandular; inner surface glabrous, except mouth and base of lobes sparsely hairy, hairs 0.1-0.4 mm long; tube c. $4 \mathrm{~mm}$ long; abaxial median lobes transversely broad-spathulate, 4-4.5 mm long, 4.5-5 mm wide, apex irregular and rounded, usually bilobed; lateral lobes elliptic, c. $4 \mathrm{~mm}$ long, $2.3-2.5 \mathrm{~mm}$ wide, apex slightly irregular, rounded to slightly retuse; adaxial median lobe-pair depressed ovate to very depressed ovate, 2.3-2.5 mm long, 6-6.5 $\mathrm{mm}$ wide, apex rounded, irregular. Stamens inserted $1.2-1.5 \mathrm{~mm}$ above base of corolla; filaments $2.2-3.7 \mathrm{~mm}$ long; anthers $0.8-1 \mathrm{~mm}$ long, lobes cristate on basal dorsal surface with narrowly triangular trichomes and with small acumen basally, connective extended to form a basal appendage $0.5-0.6 \mathrm{~mm}$ long, terminating in 4-6 narrowly triangular trichomes. Pistil 5.5-6 mm long. Mericarps 1-1.8 mm long. Fig. 4.

Flowering: February-June. Fruiting: only recorded in fruit in February.

Other specimens examined: New South Wales: North Coast: Bundjalung National Park: 20 km SW of Evans Head, Griffith s.n., May 1982, (NSW 218973); 7.5 km W of Black Rocks, Griffith s.n., 27 May 1988 (MEL, NSW 218975); Jerusalem Creek, 10 miles directly SSW of Evans Head, J.A. $\mathcal{E}$ D.J. McGillivray 1944, 26 June 1966 (NSW 229300); Jerusalem Creek Track, c. $0.6 \mathrm{~km}$ N of the Gap Road junction with road to Booroora Rest Area, Timmis s.n., 29 May 1990 (NSW 229332).

Distribution: this species is only known the Jerusalem Creek area of the Bundjalung National Park, New South Wales.

Habitat: this species occurs in a coastal, wet shrubland/heathland which is dominated by Banksia integrifolia, B. ericifolia, Allocasuarina littoralis, Hibbertia serpyllifolia, Schoenus brevifolius, Adrastaea salicifolia and Boronia falcifolia. The soil is a white siliceous sand with a high organic content.

Etymology: the specific epithet is from the Latin palustris, swampy, referring to the habitat in which this species occurs.

Notes: this species is characterised by having small flowers, spathulate non-aromatic leaves. The affinities of this species is not known. This species has been included in the modified key in this paper (see above).

Conservation status: although this species occurs in the Bundjalung National Park, it is regarded as rare and possibly endangered (Risk Code $=2 \mathrm{RCi}$ ). This species is 


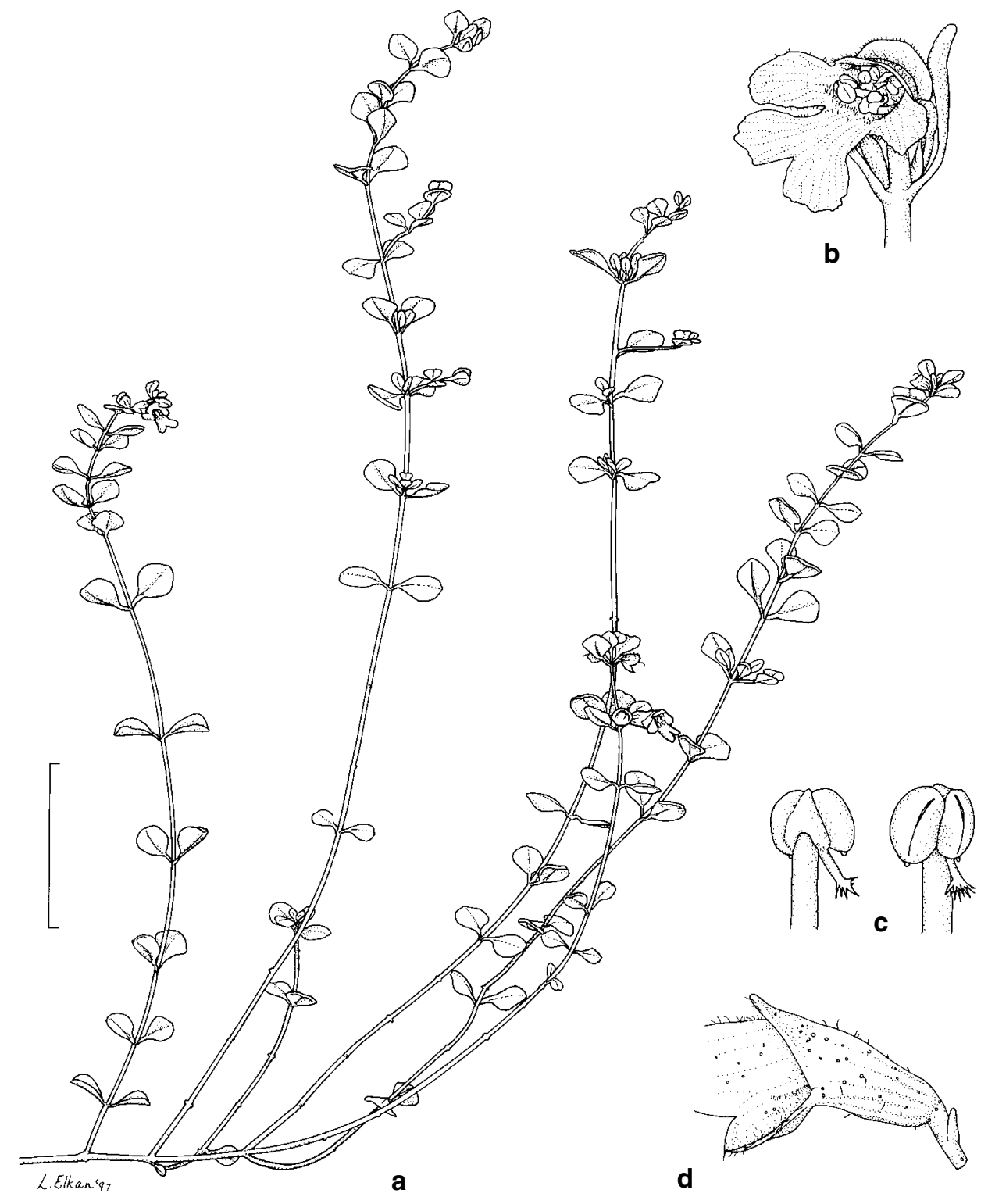

Fig. 4. Prostanthera palustris. a, flowering branchlet. b, flower in leaf axil, with other flower undeveloped. c, stamens, showing dorsal and ventral surfaces, and appendage. d, detail of calyx and prophylls (a from Conn 3471; b-d from Griffith 4359). Scale bar: $\mathrm{a}=30 \mathrm{~mm} ; \mathrm{b}=6 \mathrm{~mm}$; $=20$ $\mathrm{mm} ; \mathrm{d}=40 \mathrm{~mm}$. 
listed as 'Prostanthera sp. Bundjalung National Park (B.J. Conn 3471)' under the New South Wales Threatened Species Conservation Act 1995 No 101, p. 113, as 'Schedule 2, Vulnerable Species'.

\section{Acknowledgments}

Since 1992, the following people have generously offered assistance and advice to me during my study of Prostanthera junonis: J. Allen (Gosford City Council), S. Bell (Waratah), Dr E. Brown (NSW), A. Clements (North Sydney), R. Coveny (NSW), J. Doney (Gosford), G. Fensom (Mt Annan Botanic Gardens), D. Godden (NSW), M. Matthes (National Parks \& Wildlife Service, Hurstville), R. Miller (Bankstown Native Garden, Picnic Point), R. Payne (Umina Beach), K. Radford (then NSW), A. Rodd (Annandale), D. Tierney (Gosford), B. Timmis (Kangaroo Valley). J. Allen, J. Doney, D. O'Brien (Ourimbah). C. Manners (Ourimbah), R. Miller and R. Payne provided information on Prostanthera askania. I gratefully thank them for their help. Dr Peter Wilson (NSW) kindly provided advice on the latin descriptions and Lesley Elkan (NSW) prepared the illustrations.

\section{References}

Althofer, G.W. (1978). Cradle of Incense - The Story of Australian Prostanthera. (Society for Growing Australian Plants: [Sydney]).

Briggs, J.D. and Leigh, J.H. (1996) Rare or Threatened Australian Plants, revised edition. (CSIRO: Collingwood).

Conn B.J. (1984) A taxonomic revision of Prostanthera Labill. section Klanderia (F.v. Muell.) Benth. (Labiatae). J. Adelaide Bot. Gard. 6: 207-348.

Conn, B.J. (1992) Prostanthera. Pp. 646-662 in Harden, G.J. (ed.) Flora of New South Wales, vol. 3. (New South Wales University Press: Kensington).

Conn, B.J. (1995) Description of inflorescence axes in the genus Logania R.Br. (Loganiaceae). Kew Bull. 50: 777-783.

Conn B.J. (1996) Distribution of Prostanthera sp. 8 'Somersby', Somersby Industrial Estate, City of Gosford, NSW. Unpublished report, Australian Museum.

Tierney, D.A. (1996) Prostanthera sp. 'Somersby'; is recovery possible? Unpublished Master of Natural Resource Management thesis, University of New England.

Manuscript received 2 April 1997

Manuscript accepted 15 August 1997 